\title{
Fetal growth in different racial groups
}

\section{J. ALVEAR* AND O. G. BROOKE}

From the Department of Paediatrics, St. Mary's Hospital, Harrow Road, and Department of Child Health, St. George's Hospital, London

SUMMARY Three racial groups of mothers and their newborn babies-North European 75, Negro 75, and 'Indian' Asian 37-were matched for parity, gestational age, sex, maternal age, maternal smoking habits, and social class. Multiple anthropometric measurements, including skinfold thickness, limb circumferences, and various linear measurements were made on the mothers and their infants to determine the effects of race and smoking on fetal size. Indian-Asian mothers, though shorter and lighter than Europeans and Negroes, had similar skinfold thickness and weight : height ${ }^{2}$ ratios and gained as much weight during pregnancy. Their infants, however, were lighter than the others, and had smaller head and limb circumferences, although their linear measurements were the same. Negro and European infants were almost identical in size. We found no effect on any of the fetal measurements which could be attributed to smoking.

The wide variation in birthweight of term babies is well known. Some of this variation has been accounted for by specific factors such as maternal undernutrition (Smith, 1947), smoking (Butler et al., 1972), social deprivation (Drillien, 1957), and congenital abnormalities of one sort or another. However, much of the variation is probably genetically determined (Donald, 1939; Eveleth and Tanner, 1976) although the importance of ethnic influences remains controversial (Habicht et al., 1974; Farquharson, 1976). Ashcroft's data from the West Indies (Ashcroft et al., 1968) suggest that there is ethnic variation in physical growth, and he has pointed out that this is important in assessing nutritional status (Ashcroft, 1972). Other authors have noted ethnic differences in skinfold thickness (Robson, 1964; Malina, 1966) although these are not generally taken into account in published standards.

Differences in birthweight which are apparently due to racial differences may really be the result of variations in maternal nutrition or other environmental factors, but we lack anthropometric studies of newborn infants in racially mixed but socially homogeneous communities. We now pay a great deal of attention to fetal growth, since growth retardation puts the fetus at risk of impaired development (Drillien, 1970; Dobbing, 1974) but we cannot precisely identify the undergrown neonate in a mixed

Received 21 May 1977

*British Council Research Fellow community. This is particularly true of Indian babies, who tend to be smaller than their English or African peers (Roberts et al., 1973).

In an attempt to determine whether there are important differences in neonatal size in the three main racial groups of the British Isles (North Europeans, Negroes, and Asians originating from the Indian subcontinent, whom we shall refer to as Indians) we have measured a cohort of infants born during one year in a hospital serving a predominantly low social class immigrant area of West London. The careful matching necessary to eliminate other influences on fetal growth has also made it possible to have a fresh look at the effect of smoking on birthweight and other measurements in the neonate.

\section{Patients and methods}

187 mothers and their babies fulfilled the matching criteria described below. There were 75 Europeans, 75 Negroes, and 37 Asians. The Europeans were predominantly Irish, the Negroes came from Jamaica, Barbados, and Dominica, with a few from West Africa, and the Indians were immigrants from India, Pakistan, and Bangladesh, with a few from East Africa.

All infants born after abnormal pregnancies were excluded from the study, as were immature $(<37$ weeks' gestation) or malformed infants. None of the mothers were hypertensive or had any other general disorder. 
Matching criteria. Mothers and their infants in the three racial groups were matched in the following ways. (1) For maternal parity, up to gravida 3, after which the numbers were very small and were considered together as 'gravida 4+'. (2) For gestational age, to the nearest week. (3) For sex. (4) For maternal smoking habits-here the mothers were matched in 4 groups: (a) nonsmokers; (b) $<15$ cigarettes/day during pregnancy; (c) 15-40 cigarettes/day during pregnancy; (d) $>40$ cigarettes/day during pregnancy. Information on smoking habits was obtained after the infant was measured. (5) For maternal ageprecise matching was not practicable in the time available but as far as possible mother-infant pairs were matched for maternal age, and mean maternal age was not significantly different in the three racial groups. (6) For social class-all mothers were from social class 4 or 5 by husband's occupation.

Maternal measurements. Maternal nutrition was judged by weight-height index $\left(w / h^{2}\right)$ at booking, weight gained during pregnancy, mid-upper arm circumference, and triceps fat-fold in the puerperium. Weights and heights were taken from clinic records. Mid-upper arm circumference was measured with a fibreglass tape to the last completed mm (Jelliffe, 1966). Triceps fat-fold was measured with a Harpenden caliper to the last completed $0.1 \mathrm{~mm}$ (Tanner and Whitehouse, 1975). No attempt was made to assess maternal nutrient intake during pregnancy by dietary histories because we thought these unreliable.

Infant measurements. The following measurements were made on the infants within 24 hours of birth. (1) Weight to the nearest $10 \mathrm{~g}$ on a Marsden beam balance. (2) Crown-heel length, crown-rump length, and rump-heel length to the last completed $\mathrm{mm}$ (Tanner et al., 1966) on a horizontal stadiometer made in the department. (3) Elbow-wrist length, measured to the last completed $\mathrm{mm}$ from the olecranon to the dorsal surface of the fully flexed wrist, using a specially designed measuring board. (4) Knee-heel length, measured similarly from the heel to the upper surface of the knee in $90^{\circ}$ of flexion. (5) Occipitofrontal head circumference to the nearest $1 \mathrm{~mm}$. (6) Mid-upper arm circumference to the last completed mm (Jelliffe, 1966). (7) Maximum calf circumference to the last completed $\mathrm{mm}$. (8) Biiliac circumference (at the level of the superior iliac spines) to the last completed $\mathrm{mm}$. A fibreglass tape was used for all circumferential measurements. (9) Triceps, subscapular, and periumbilical skinfold thickness, measured to the last completed $0.1 \mathrm{~mm}$ using a Harpenden caliper. Triceps and subscapular skinfolds were measured at the sites described by Tanner and Whitehouse (1975). Periumbilical skinfold was measured by applying the calipers to a fold of skin lifted from the anterior abdominal wall about $1 \mathrm{~cm}$ below and to the left of the umbilicus. In all skinfold measurements the reading finally recorded was that obtained when there was no further compression of the fold by the caliper (in other words when the needle stopped moving). Three measurements were taken at each site.

\section{Results}

\section{Data on the mothers.}

Nutrition (Table 1). The Indian mothers were shorter and lighter than the Europeans and Negroes, but their daily weight gain was the same. The Negro women were heavier at booking than the Indians and Europeans, but gained less weight during pregnancy. There were no significant differences in weight/height ${ }^{2}$ ratio, triceps skinfold thickness, and mid-upper arm circumference between any of the racial groups. All the mothers remained well during pregnancy and the data do not suggest any important differences in nutrition during this time.

Table 1 Anthropometric data on mothers in three racial groups (with standard deviations)

\begin{tabular}{|c|c|c|c|}
\hline & $\begin{array}{l}\text { Negroes } \\
(n=75)\end{array}$ & $\begin{array}{l}\text { Europeans } \\
(n=75)\end{array}$ & $\begin{array}{l}\text { Indian Asians } \\
(n=37)\end{array}$ \\
\hline Height (m) & $\begin{array}{r}1.64 \\
(0.07)\end{array}$ & $\begin{array}{cc}1.62 & t=4.9 \\
(0.06) P & <0.00\end{array}$ & $\begin{array}{c}1.57 \\
1(0.05)\end{array}$ \\
\hline $\begin{array}{l}\text { Weight at } \\
\text { booking }(\mathrm{kg}) \\
\text { Weight at term }(\mathrm{kg})\end{array}$ & $\begin{array}{l}63.7 \quad t=2.0 \\
(16.3) P<0.05 \\
72.5 \\
(16.3)\end{array}$ & $\begin{array}{lr}59.4 & t=2.2 \\
(8.6) & P<0.05 \\
70.2 & t=3.3 \\
(8.4) & P<0.01\end{array}$ & $\begin{array}{l}55 \cdot 5 \\
(9 \cdot 1) \\
64 \cdot 2 \\
(9 \cdot 5)\end{array}$ \\
\hline $\begin{array}{l}\text { Weight-height index } \\
\left(w / h^{2}\right) \text { at booking } \\
\text { Weight gain/ day (g) }\end{array}$ & $\begin{array}{l}23 \cdot 4 \\
(4 \cdot 5) \\
53 \cdot 0 \\
(17 \cdot 1)\end{array}$ & $\begin{array}{l}22 \cdot 9 \\
(2 \cdot 5) \\
62 \cdot 8 \\
(22 \cdot 9)\end{array}$ & $\begin{array}{c}22 \cdot 5 \\
(3 \cdot 1) \\
57 \cdot 8 \\
(22 \cdot 4)\end{array}$ \\
\hline Triceps skinfold (mm) & $\begin{array}{l}16 \cdot 6 \\
(6 \cdot 7)\end{array}$ & $\begin{array}{l}16 \cdot 2 \\
(5 \cdot 0)\end{array}$ & $\begin{array}{l}18 \cdot 6 \\
(6 \cdot 7)\end{array}$ \\
\hline $\begin{array}{l}\text { Mid-upper arm } \\
\text { circumference }(\mathrm{cm})\end{array}$ & $\begin{array}{l}25 \cdot 9 \\
(3 \cdot 4)\end{array}$ & $\begin{array}{l}25 \cdot 2 \\
(2 \cdot 1)\end{array}$ & $\begin{array}{l}24 \cdot 6 \\
(4 \cdot 0)\end{array}$ \\
\hline
\end{tabular}

Parity. Average parity was 1.7 in each of the three racial groups.

Maternal age. It proved impossible to match maternal ages precisely but there were no significant differences in the mean age of the mothers in the three groups: Europeans $25 \cdot 3$ years (SD 5.1), Negroes 23. 6 years (SD 5.9), Asians 25. 4 years (SD 5.6).

Gestational age. Matching ensured no difference in gestational age in the three groups: Europeans 39.7 weeks (SD 0.9), Negroes 39.6 weeks (SD 1.0), Asians $39 \cdot 5$ weeks (SD 1.0). 
Social class. The social class $4 / 5$ ratio was $1 \cdot 9: 1$ for the Europeans, 1·3:1 for the Negroes, and 4·3:1 for the Asians.

Smoking habits. European mothers smoked more than the Negroes. The Asian women did not smoke at all. Very few Negro women smoked heavily, but of the European smokers $8 \%$ smoked more than $\mathbf{4 0}$ cigarettes/day and $56 \%$ smoked $15-40$ cigarettes/day.

Data on the infants (Table 2).

Europeans vs Negro. There were no significant differences in any of the measurements except in biiliac circumference, which was smaller in the Negroes $(P<0.05)$, and triceps skinfold, which was larger $(\mathrm{P}<0.001)$.

Europeans vs Asian. The Asian infants were lighter $(\mathbf{P}<0.01)$; they had smaller weight-length ${ }^{2}$ ratio $(P<0.01)$; they had smaller heads $(P<0.001)$; and their arm and leg circumferences were smaller $(\mathrm{P}<0.05$ and $<0.01$ respectively). The triceps skinfold of the Asian babies was significantly greater than that of the Europeans $(P<0 \cdot 01)$, although there was no difference in the other measurements. Since their limb lengths were similar, the smaller limb circumferences of the Asian babies implies that they had less lean tissue than the Europeans.

Negro vs Asian. In general we found the same differences between the Negro and Asian babies as we found between the Europeans and Asians. However, the Negroes had greater triceps skinfold thickness than the Asians $(P<0 \cdot 001)$.

There were no significant differences in any of the linear measurements between the three groups of infants.

Effects of smoking. Although the numbers were small, the mothers were well enough matched for factors known to be important in determining birth size for an assessment to be made of the effects of smoking on the anthropometric measurements in their babies. For this comparison the European and Negro groups were combined to give 106 smoking and nonsmoking pairs fully matched in the other ways already described. There were no significant differences in anthropometric measurements between infants in the various categories of maternal smoking $(<15$ day, 15-40/day, $>40 /$ day), so we have compared the smokers' babies as a group with their nonsmoking controls (Table 3). None of the measurements differed statistically between the two groups.

Table 3 Anthropometric data on babies of smoking and nonsmoking mothers (with standard deviations)

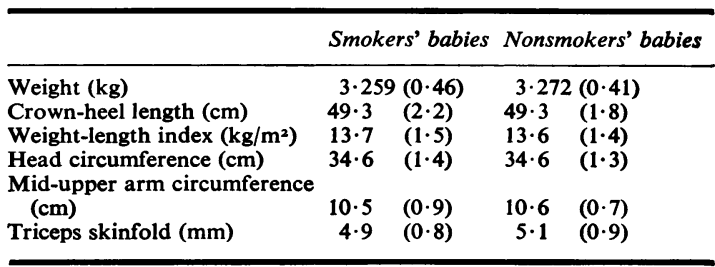

Relationship between maternal and infant fatness. The Fig. shows the correlation of maternal and neonatal triceps skinfold thickness. No linear relationship is apparent among these sets of measurements.

\section{Discussion}

Although variations in human size are interesting to the anthropologist, their clinical importance lies in their relevance to nutrition. Since the assessment of growth and physical development relies almost entirely on the use of standard growth charts and tables, we must be sure that these are appropriate to the population under scrutiny.

Table 2 Anthropometric data on babies in three racial groups (with standard deviations)

\begin{tabular}{|c|c|c|c|c|c|c|c|c|}
\hline \multirow[b]{2}{*}{$\begin{array}{l}\text { Weight (kg) } \\
\text { Crown-heel length }(\mathrm{cm}) \\
\text { Weight-length index }\left(\mathrm{kg} / \mathrm{m}^{2}\right) \\
\text { Crown-rump length }(\mathrm{cm}) \\
\text { Rump-heel length }(\mathrm{cm}) \\
\text { Forearm length }(\mathrm{cm}) \\
\text { Lower leg length }(\mathrm{cm}) \\
\text { Head circumference }(\mathrm{cm}) \\
\text { Mid-upper arm circumference (cm) } \\
\text { Maximum calf circumference (cm) } \\
\text { Biiliac circumference (cm) } \\
\text { Triceps skinfold (mm) } \\
\text { Subscapular skinfold (mm) } \\
\text { Periumbilical skinfold (mm) }\end{array}$} & \multicolumn{2}{|c|}{$\begin{array}{l}\begin{array}{l}\text { Negroes } \\
(n=75)\end{array} \\
3.217(0.42)\end{array}$} & & \multicolumn{2}{|c|}{$\begin{array}{l}\text { Europeans } \\
(n=75)\end{array}$} & \multirow[b]{2}{*}{$\begin{array}{l}t=2.9, P<0.01 \\
t=3.2, P<0.01\end{array}$} & \multicolumn{2}{|c|}{$\begin{array}{c}\begin{array}{c}\text { Indian Asians } \\
(n=37)\end{array} \\
2.988(0.49)\end{array}$} \\
\hline & $\begin{array}{r}3 \cdot 21 \\
48 \cdot 8 \\
13 \cdot 7 \\
32 \cdot 0 \\
22 \cdot 8 \\
8 \cdot 4 \\
12 \cdot 3 \\
34 \cdot 4 \\
10 \cdot 3 \\
11 \cdot 1 \\
25 \cdot 6 \\
6 \cdot 1 \\
4 \cdot 5 \\
4 \cdot 0\end{array}$ & $\begin{array}{l}(0 \cdot 42) \\
(2 \cdot 0) \\
(1 \cdot 4) \\
(1 \cdot 6) \\
(4 \cdot 1) \\
(0 \cdot 4) \\
(0 \cdot 6) \\
(1 \cdot 2) \\
(0 \cdot 4) \\
(0 \cdot 8) \\
(1 \cdot 7) \\
(1 \cdot 1) \\
(0 \cdot 9) \\
(1 \cdot 0)\end{array}$ & $\begin{array}{c}t=2.6, P<0.05 \\
t=11 \cdot 2, P<0.001\end{array}$ & $\begin{array}{r}3 \cdot 26 \\
49 \cdot 3 \\
13 \cdot 9 \\
32 \cdot 2 \\
23 \cdot 1 \\
8 \cdot 3 \\
12 \cdot 3 \\
34 \cdot 7 \\
10 \cdot 5 \\
11 \cdot 3 \\
26 \cdot 3 \\
4 \cdot 3 \\
4 \cdot 6 \\
4 \cdot 1\end{array}$ & $\begin{array}{l}(0 \cdot 43) \\
(1 \cdot 6) \\
(1 \cdot 5) \\
(1 \cdot 3) \\
(1 \cdot 1) \\
(0 \cdot 4) \\
(0 \cdot 6) \\
(1 \cdot 3) \\
(0 \cdot 8) \\
(0 \cdot 7) \\
(1 \cdot 6) \\
(0 \cdot 9) \\
(0 \cdot 9) \\
(1 \cdot 0)\end{array}$ & & $\begin{array}{r}2 \cdot 98 \\
48 \cdot 8 \\
12 \cdot 3 \\
31 \cdot 5 \\
22 \cdot 9 \\
8 \cdot 3 \\
12 \cdot 3 \\
33 \cdot 8 \\
10 \cdot 1 \\
10 \cdot 7 \\
25 \cdot 8 \\
4 \cdot 9 \\
4 \cdot 5 \\
4 \cdot 0\end{array}$ & $\begin{array}{c}8(0.49) \\
(1 \cdot 8) \\
(1 \cdot 7) \\
(1 \cdot 4) \\
(1 \cdot 0) \\
(0.4) \\
(0.6) \\
(1 \cdot 1) \\
(0.9) \\
(0.9) \\
(2 \cdot 5) \\
(1 \cdot 1) \\
(0.9) \\
(0.9)\end{array}$ \\
\hline
\end{tabular}




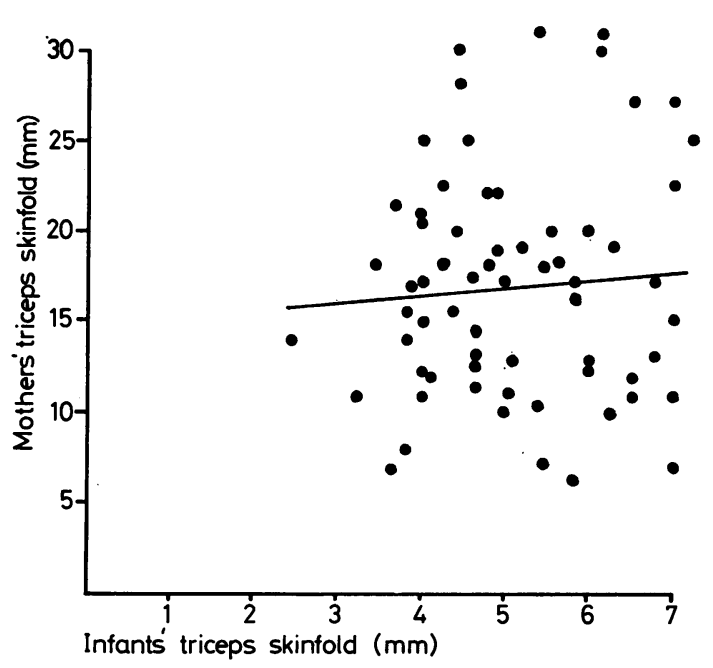

Fig. Relationship between mother's triceps skinfold and that of her infant in 65 mother-infant pairs.

The Indian peoples of Britain are generally considered to be shorter and lighter than the European and Negro populations, and the birthweight of their babies tends to be lower (Stroud, 1971; Arthurton, 1972; Roberts et al., 1973). Our study confirms these findings. Nevertheless, we continue to judge the growth of their children by European and North American standards, which may be inappropriate. One reason for this is the uncertainty about the reason for the smaller size of the Indians. If it is due to poor nutrition in the women, or to socioeconomic deprivation-and there is evidence to suggest that upper class Indians in India have a growth potential similar to Caucasians (Rosa and Tursham, 1970)then the Western standards may be appropriate. If, however, the immigrant population are genetically small, or small because of the effects of poor nutrition several generations ago, we should have new standards with which to assess their growth. This is particularly important in determining fetal growth retardation, since undergrown neonates may have later developmental problems (Drillien, 1970), and we rely heavily on birthweight in relation to gestational age in diagnosing the small-for-dates infant.

Our data suggest that the energy intake of the Indian mothers in our study was adequate, since they were no thinner than the Negroes and Europeans, and their daily weight increase during pregnancy was the same as the Europeans, contrary to a previous report (Shaper et al., 1969), and greater than that of the Negroes. Their babies also received adequate energy in utero, since their subcutaneous fat reserves were similar to those of the Negro and European infants, and linear growth was no different in the three groups of infants. Although it is possible that suboptimal intake of vitamins, trace elements, or minerals might have affected growth in the Indian babies, or conceivably that their mothers' dietary protein was inadequate we think this is unlikely. None of the Indian mothers showed any clinical evidence of nutritional deficiency such as osteomalacia, and most were nonvegetarian Muslims, whose diet is certainly as varied as that of West Indian women of similar social class. Even though a few of the Indians were vegetarian, it has been shown that strict vegetarians, who might be expected to develop nutritional deficiencies, remain healthy during pregnancy and have babies of normal weight (Thomas and Ellis, 1977). Indian women are known to have a diet which is relatively deficient in calcium ky the third trimester (Matter and Wakefield, 1971), but their average daily calcium intake is still about 14 times the total content of calcium in the neonatal skeleton, so this is unlikely to have affected growth in any way.

The possibility that Indian infants are small because of malnutrition in previous forebears is difficult to disprove. There is evidence that undernutrition in previous generations leaves its mark on their descendants, even though nutrition and living standards have improved (Ounsted and Ounsted, 1973). This is the case among certain of the North American Indian tribes whose living standard was poor in previous centuries, and who remain undersized in comparison with the descendants of better favoured tribes (Adams and Niswander, 1968). However, if it takes generations of improved nutrition before fetal size alters materially, the boundaries between environmental and racial influences on fetal growth tecome blurred and it is no longer important to differentiate between them; in either case special growth standards are necessary.

We believe that genetic differences are the chief factor in the small size of Indian infants because, although it is undeniable that there is much undernutrition in the Indian subcontinent, malnutrition has been equally prevalent in the West Indies, whence most of the Negroes came, and was a serious problem in Ireland during much of the 19th century. In spite of this, the Negro and European (mainly Irish) babies were of average weight by British standards. Furthermore, the weights of the Negro infants in our study were within $0.8 \%$ of those of West Indian Negroes korn in Jamaica (Roopnarinesingh et al., 1971), a much larger population exposed to similar risk in earlier generations.

Another source of variation in birthweight is body fat. Our studies do not suggest that the Indian babies were thinner than European or Negro babies, and neither were their mothers. We have been unable to 
detect the reported trend for fatter women to have fatter babies (Whitelaw, 1976). Possibly a larger sample would have shown such a correlation but it would certainly be weak. The amount of subcutaneous fat in the triceps skinfold has been shown to be less in Negro children than in children from other races of comparable body size (Robson, 1964; Malina, 1968; Ashcroft et al., 1968). Our results show that this difference in body fat distribution is reversed in fetal life, since the triceps skinfold in the Negro infants was significantly greater than in the other racial groups.

We were surprised to find no detectable effect of smoking on fetal size in our populations of European and Negro infants. The small reductions in weight, mid-upper arm circumference, and triceps skinfold in the smokers' babies might have become significant with larger numbers but are unlikely to be of much biological importance. Since a number of the mothers were heavy smokers, this raises doubt as to whether smoking alone has an important influence on fetal growth. Social class could well be the crucial factor here, since smoking is more frequent in lower social class groups, and may be an index of a certain type of mother who tends to have babies of low birthweight (Yerushalmy, 1964, 1971). More information is needed about the effects of smoking on human fetal growth, using careful matching of controls on a larger scale than we were able to attempt. Perhaps we have accepted the findings of large epidemiolgical surveys (Lowe, 1959; Kullander and Källén, 1971; Butler et al., 1972) too uncritically. For example, it has been difficult until quite recently to distinguish low birthweight due to immaturity from that due to fetal growth retardation by examining hospital records. At least one study (Terris and Gold, 1969) did not make this distinction in assessing the effects of smoking. If the main result of smoking were to cause early delivery rather than growth retardation, the effect on birthweight would not appear in our study, since we excluded preterm deliveries.

\section{References}

Adams, M. S., and Niswander, J. D. (1968). Birth-weight of North American Indians. Human Biology, 40, 226-234.

Arthurton, N. W. (1972). Immigrant children and the dayto-day work of a paediatrician. Archives of Disease in Childhood, 47, 126-130.

Ashcroft, M. T. (1972). Triceps skinfold measurements in nutritional assessment of Jamaican children. Transactions of the Royal Society of Tropical Medicine and Hygiene, 66, 953-954.

Ashcroft, M. T., Bell, R., and Nicholson, C. C. (1968). Anthropometric measurements of Guyanese schoolchildren of African and East Indian racial origins. Tropical and Geographical Medicine, 20, 159-171.

Butler, N. R., Goldstein, H., and Ross, E. M. (1972). Cigarette smoking in pregnancy: its influence on birth- weight and perinatal mortality. British Medical Journal, 2, 127-130.

Dobbing, J. (1974). The later growth of the brain and its vulnerability. Pediatrics, 53, 2-6.

Donald, H. P. (1939). Sources of variation in human birthweights. Proceedings of the Royal Society of Edinburgh. Series B (Biology), 54, 91-1080.

Drillien, C. M. (1957). The social and economic factors affecting the incidence of premature birth. I. Premature births without complications of pregnancy. Journal of Obstetrics and Gynaecology of the British Empire, 64, 161-184.

Drillien, C. M. (1970). The small-for-dates infant: etiology and prognosis. Pediatric Clinics of North Americ, 17, 9-24.

Eveleth, P. B , and Tanner, J. M. (1976). World-wide Variation in Human Growth. International Biological Programme Series No. 8. Cambridge University Press, London.

Farquharson, S. M. (1976). Growth patterns and nutrition in Nepali children. Archives of Disease in Childhood, 51, 3-12.

Habicht, J. P., Martorell, R., Yarbrough, C., Malina, R. M., and Klein, R. E. (1974). Height and weight standards for preschool children. Lancet, 1, 611-614.

Jelliffe, D. B. (1966). The Assessment of the Nutritional Status of the Community. Monograph Series No. 53. WHO, Geneva.

Kullander, S., and Källén, B. (1971). A prospective study of smoking and pregnancy. Acta Obstetrica et Gynecologica Scandinavica, 50, 83-94.

Lowe, C. R. (1959). Effects of mothers' smoking habits on birth weight of their children. British Medical Journal, 2, 673-676.

Malina, R. M. (1966). Patterns of development in skinfolds of negro and white Philadelphia children. Human Biology, 38, 89-103.

Matter, S. L., and Wakefield, L. M. (1971). Religious influence on dietary intake and physical condition of indigent, pregnant Indian women. American Journal of Clinical Nutrition, 24, 1097-1106.

Ounsted, M., and Ounsted, C. (1973). On Fetal Growth Rate. Clinics in Developmental Medicine No. 46. Heinemann, London.

Roberts, P. D., James, H., Petrie, A., Morgan, J. O., and Hoff brand, A. V. (1973). Vitamin $B_{12}$ status in pregnancy among immigrants to Britain. British Medical Journal, 3, 67-72.

Robson, J. R. K. (1964). Skinfold thicknesses in apparently normal African adolescents. Journal of Tropical Medicine and Hygiene, 67, 209-210.

Roopnarinesingh. S. S., Morris, D., and Persaud, T. V. P. (1971). Birth weight of Jamaican babies. Journal of Tropical Pediatrics and Environmental Child Health, 17, 11-14.

Rosa, F. W., and Turshen, M. (1970). Fetal nutrition. Bulletin of the World Health Organization, 43, 785-800.

Shaper, A. G., Leonard, P. J., Jones, K. W., and Jones, M. (1969). Biochemical changes, blood pressure and body build during pregnancy in African and Indian primigravidae in East Africa. East African Medical Journal, 46, 290-308.

Smith, C. A. (1947). Effect of wartime starvation in Holland upon pregnancy and its product. Americon Journal of Obstetrics and Gynecolcgy, 53, 599-608.

Stroud, C. E. (1971). Nutrition and the immigrant. British Journal of Hospital Medicine, 5, 629-634.

Tanner, J. M., and Whitehouse, R. H. (1975). Revised standards for triceps and subscapular skinfolds in British children. Archives of Disease in Childhood, 50, 142-145.

Tanner, J. M., Whitehouse, R. H., and Takaishi, M. (1966). standards from birth to maturity for height, weight, height velocity and weight velocity. Archives of Disease in Childhood, 41, 454-471; 613-635. 
Terris, M., and Gold, E. M. (1969). An epidemiological study of prematurity. Relation to smoking, heart volume, employment and physique. American Journal of Obstetrics and Gynecology, 103, 358-370.

Thomas, J., and Ellis, F. R. (1977). The health of vegans during pregnancy. Proceedings of the Nutrition Society, 36, 46A.

Whitelaw, A. G. L. (1976). Influence of maternal obesity on subcutaneous fat in the newborn. British Medical Journal, 1, 985-986.

Yerushalmy, J. (1964). Mothers' cigarette smoking and survival of the infant. American Journal of Obstetrics and Gynecology, 88, 505-578.

Yerushalmy, J. (1971). Relationship of parents' cigarette smoking to outcome of pregnancy-implications as to the problem of inferring causation from observed associations. American Journal of Epidemiology. 93, 443-456.

Correspondence to Dr O. G. Brooke, Department of Child Health, St. George's Hospital Medical School, Cranmer Road, Tooting, London SW17 ORE. 